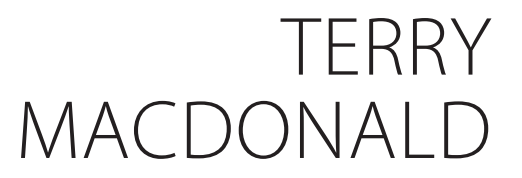

\title{
Democratizing Global
} 'Bodies Politic': Collective Agency, Political Legitimacy, and the Democratic Boundary Problem

\begin{abstract}
This article outlines a new approach to answering the foundational question in democratic theory of how the boundaries of democratic political units should be delineated. Whereas democratic theorists have mostly focused on identifying the appropriate population-group - or demos - for democratic decisionmaking, it is argued here that we should also take account of considerations relating to the appropriate scope of a democratic unit's institutionalized governance capabilities - or public power. These matter because democratically legitimate governance is produced not only through the decision-making agency of a demos, but also through the institutionally distinct sources of political agency that shape the governance capabilities of public power. To develop this argument, the article traces a new theoretical account of the normative and institutional sources of collective agency, political legitimacy, and democratic boundaries, and illustrates it through a democratic reconstruction of the classical body politic metaphor. It further shows how this theoretical account lends strong prescriptive support to pluralist institutional boundaries within democratic global governance.
\end{abstract}

Keywords: global democracy; political legitimacy; collective agency; democratic boundary problem; body politic.

\section{Introduction}

In the present era of globalization, the extensive exercise of power and interaction among people across the borders of democratic states has intensified interest in the so-called democratic 'boundary problem,' concerned with the question: what should be the social and institutional unit within which democracy is to be practiced ${ }^{1}$ The unit for democratic governance can be defined in two, functionally interdependent, dimensions. The first delineates the population group that is institutionally empowered to participate in collective decisionmaking through some democratic social choice procedure - which we can call the demos. The second delineates the range of issues on which the demos is empowered to take decisions through the availability of suitable institutionalized

1 Robert Dahl, After the Revolution? Authority in a Good Society (New Haven and London: Yale University Press, 1970); Frederick Whelan. 'Prologue: Democratic Theory and the Boundary Problem' in J. Roland Pennock and John W. Chapman (eds.), Liberal Democracy (New York: New York University Press, 1983); Christian List and Mathias Koenig-Archibugi 'Can There Be a Global Demos? An Agency-Based Approach', Philosophy \& Public Affairs 38/1 (2010), 76-110; David Miller 'Democracy's Domain', Philosophy \& Public Affairs 37/3 (2009), 201-228; Robert Goodin 'Enfranchising All Affected Interests, and Its Alternatives', Philosophy \& Public Affairs 35/1 (2007), 4068; Arash Abizadeh 'Democratic Theory and Border Coercion: No Right to Unilaterally Control Your Own Borders', Political Theory 36/1 (2008), 37-65. 
governance capabilities - which we can call public power. ${ }^{2}$

The near-exclusive focus in contemporary literature on democratic boundaries has been on the first side of this two-dimensional institutional problem. In his now classic discussion of the democratic boundary problem, Frederick Whelan is typical in equating the democratic boundary problem with the problem of 'defining or bounding [...] the membership of the democratic body, or citizenry.' ${ }^{3}$ In more recent discussion, others have characterized it as the problem of 'constituting the demos,'4 or of locating 'democracy's domain.'5 This focus is so strong that the democratic boundary problem is now widely referred to as the 'demos problem' - implying that we will be in a position to settle the broader question of the appropriate social and institutional unit for democracy just as soon as we properly understand the nature of, and social conditions for, a demos.

I argue here that in considering the problem of democratic boundaries it is a mistake to focus only on the question of how we should constitute democracy's demos, while neglecting the parallel question of how we should constitute democracy's framework of public power. ${ }^{6}$ It is my contention that questions about the boundaries of democratic public power introduce normative and institutional considerations that have some significant degree of independence from those raised by questions about the boundaries of the demos, and these require their own careful analysis in judging the best solution to the overarching democratic boundary problem. These considerations have some independence, I argue, because legitimate democratic governance is produced not only through the decision-making agency of a demos, but also through the institutionally distinct sources of political agency that shape the governance capabilities of public power. This matters politically because taking adequate account of public power considerations lends strong prescriptive support to a pluralist

2 Robert Dahl (1970) and David Miller (2009) refer to this distinction as one between the 'domain' and the 'scope' of a democratic unit, but here I prefer the language of 'demos' and 'public power': whereas the terms 'domain' and 'scope' evoke a spatial image of democratic units and their boundaries, the terms 'demos' and 'public power' evoke an agentic image, more congenial to the substantive arguments I advance here. I note further that in referring to 'scope' these authors focus on the scope of content in a given decision-making agenda, whereas my reference instead to 'public power' emphasizes instead the underlying governance capabilities which structurally shape and constrain the range of agendas that a demos is empowered to pursue (whatever the content of the agenda it actually pursues in any instance).

3 Whelan (1983), p. 14.

4 List and Koenig-Archibugi (2010).

5 Miller (2009).

6 While questions about the constitution of public power have been considered extensively within other areas of democratic theory, they have largely been treated as issues related to achieving legitimate governance internal to a democratic unit, the boundaries of which have been already settled; the idea that these considerations may have implications also for the delineation of the boundaries of a democratic unit is what I claim has not yet been systematically explored. 
approach to global democratic institution-building, ${ }^{7}$ which endorses the direct democratic control of multiple existing state and non-state institutions, in contrast to more widely advocated nationalist or cosmopolitan institutional boundaries of democratic global governance.

I develop this analysis in three steps. I begin by elaborating a collective agency account of the sources of democratic political legitimacy, which supplies the salient normative criteria for evaluating democratic boundaries. Here I explain the functionally interdependent roles played by the distinct political agencies of the demos and public power in producing such legitimacy: the political agency of the demos is exercised through the institutionalized collective decision-making theorists call 'social choice,' while the distinct political agency of 'public power' is exercised instead through the production of the institutionalized governance capabilities required to carry out democratic decisions; and both together are required to achieve legitimate democratic governance. Next, I move from normative to institutional analysis, and sketch a broad institutional account of how the political agency of public power can make some distinct contributions to the political legitimacy of democratic institutions, via its development and operation in dynamic interaction with the agency of a demos. Here I illustrate my institutional arguments via a democratic reconstruction of the old theoretical metaphor of the body politic and its ruling 'mind,' in which the dynamic relationships among multiple collective agencies within a legitimate democratic unit can be vividly captured. Finally, I consider the implications of this general institutional account for the more specific challenges of democratic institutionbuilding and boundary-drawing in contemporary global politics - explaining how my theoretical arguments together support what I call pluralist institutional boundaries of democratic global governance. The overall analytic method underpinning these arguments can be described as 'realist' 8 or 'interpretive' ${ }^{\text {' }}$ in character, insofar as it aims not to articulate a philosophical ideal of democratic political morality abstracted from practice, but rather, as Charles Taylor puts it, to articulate 'the kind of common understanding' of democracy and democratic legitimacy 'that enables us to carry out the collective practices' of democratic

7 Nico Krisch, Beyond Constitutionalism: The Pluralist Structure of Postnational Law (Oxford: Oxford University Press, 2011); Nico Krisch, 'Liquid Authority in Global Governance', International Theory 9/2 (2017), 237-260; Kate Macdonald and Terry Macdonald, 'Democracy in a Pluralist Global Order: Corporate Power and Stakeholder Representation', Ethics and International Affairs 24/1 (2010), 19-43; Kate Macdonald and Terry Macdonald, 'Liquid Authority and Political Legitimacy in Transnational Governance', International Theory 9/2, (2017), 329351; Terry Macdonald, 'Anti-power, Agency, and the Republican Case for Global Institutional Pluralism', in Barbara Buckinx, Jonathan Trejo-Mathys and Timothy Waligore (eds.), Domination and Global Political Justice: Conceptual, Historical, and Institutional Perspectives (New York: Routledge, 2015).

8 Bernard Williams, In the Beginning was the Deed: Realism and Moralism in Political Argument (Princeton University Press, 2005).

9 Charles Taylor, Modern Social Imaginaries (Duke University Press, 2004). 
life under the real political conditions of globalization. ${ }^{10}$

\section{The collective agency account of democratic political legitimacy: Understanding the functional interdependence of the demos and public power}

The boundaries of a democratic unit comprise a key structural element of its overall institutional scheme; as such, the normative principles we apply in delineating democratic boundaries should be the same as those applied in designing and justifying all the other institutions that make up a functioning democracy. At the most general level, I take it that democratic institutions are best justified as means of generating normative political legitimacy in practices of governance, where legitimacy is understood as the institutional quality of being worthy of political support by real political actors in some concrete operational context). ${ }^{11}$ Standards or principles of political legitimacy thus articulate the conditions that institutions must satisfy if they are to count as support-worthy in this sense.

Working from this conceptual starting-point, it follows that democratic boundaries must be delineated based on some underlying account of how they contribute, as constitutive features of wider democratic institutions, to generating such legitimacy. The questions of what are the normative sources of political legitimacy in general - and the democratic sources of political legitimacy in particular - raise large theoretical controversies that cannot be fully surveyed or settled here. For the present purposes, it is sufficient to identify the very general collective agency account that I adopt as the basis for my normative analysis here, and to situate it in relation to other familiar views. ${ }^{12}$

There are many competing theoretical accounts of the normative sources of political legitimacy in general, and its democratic sources in particular - not all of which invoke any idea of collective agency. Within recent liberal political philosophy, and some associated democratic theories, it has been common to link normative political legitimacy instead to some special procedural, ${ }^{13}$

\footnotetext{
10 Ibid., p. 24.

11 Allen Buchanan and Robert Keohane, 'The Legitimacy of Global Governance Institutions', Ethics and International Affairs 20/4 (2006), 405-437; Buchanan The Heart of Human Rights (Oxford: Oxford University Press, 2014); Macdonald (2016); Macdonald (2018).

12 Although I cannot undertake here a sustained defense of this view of the sources and limits of democratic legitimacy, I assume that the collective agency account of democratic legitimacy is sufficiently widely endorsed that an argument about the democratic boundary problem developed from within it can generate prescriptive conclusions with strong normative force.

13 John Rawls, Political Liberalism (New York: Columbia University Press, 1996).
} 
substantive, ${ }^{14}$ or non-ideal ${ }^{15}$ moral standards for the functioning of political institutions, or alternatively to some epistemic standards for institutional decision-making. ${ }^{16}$ These 'moral' or 'epistemic' accounts typically recognise democratic institutions as producing legitimacy by complying with underlying moral obligations towards political equality, ${ }^{17}$ or by promoting morally or epistemically good - 'rational,' 'reasonable,' or 'correct' - political decisions. ${ }^{18}$

But alongside these moral and epistemic accounts is a distinct family of theories that instead identify the normative source of political legitimacy with some conception of collective agency - and it is an account of this kind that I adopt here. Such collective agency accounts hold that democratic institutions generate legitimacy not by discharging moral obligations or promoting good decisions, but rather by supporting some kind of collective self-determination within groups. Institutions that empower collective agency are support-worthy, on this view, as a direct corollary of the respect that is due to the political agency of individual members of groups as expressed through their collective activities, directed towards some substantive 'common interests.'19 Here the empowerment of collective agency is accorded intrinsic political value, as a foundational source of political legitimacy. This means that it is regarded as politically respect-worthy even if its decision-making structures or outcomes depart in some way from moral or epistemic ideals. What is legitimate is thus not necessarily equivalent to what is judged to be just, rational, or otherwise correct by philosophical or political elites. ${ }^{20}$

14 Eva Erman, 'Global political legitimacy beyond justice and democracy?', International Theory 8/1 (2015), $29-62$.

15 Laura Valentini, 'Assessing the global order: justice, legitimacy, or political justice?', Critical Review of International Social and Political Philosophy 15/5, (2012), 593-612.

16 Joshua Cohen, 'An Epistemic Conception of Democracy', Ethics, 97/1, (1986), 26-38.

17 Charles Beitz, Political Equality: An Essay in Democratic Theory (Princeton: Princeton University Press, 1989); Brian Barry 'Is democracy special?' in Essays in Political Theory: Democracy and Power (Vol. 1) (Oxford: Clarendon Press, 1991), 24-60.

18 Hélène Landemore, Democratic reason: Politics, collective intelligence, and the rule of the many (Princeton University Press, 2012); Jonathan Quong, Liberalism without Perfection (Oxford University Press, 2011).

19 Terry Macdonald, 'Institutional facts and principles of global political legitimacy', Journal of International Political Theory 12/2, (2016), 134-151; Macdonald and Macdonald (2017); Terry Macdonald, 'Sovereignty, democracy, and global political legitimacy', in Chris Brown and Robyn Eckersley (eds.), Oxford Handbook of International Political Theory (Oxford: Oxford University Press 2018). By political agency here I mean politically consequential activity guided by some respect-worthy set of judgment-based political attitudes - whether these take the form of beliefs, emotions, or evaluative dispositions otherwise described. Such political agency can be understood as 'collective' in character when the attitudes that motivate the consequential activity are in some appropriate sense shared among many individuals. For brevity, these shared attitudes can be called 'common interests.'

20 As such, normative principles of political legitimacy oriented towards the empowerment of collective action can be said to embody a distinctively political form of normativity, as distinct from more commonly elaborated strategic, moral, or legal forms. While it is certainly possible to evaluate principles of legitimacy in terms of moral (as well as strategic, legal, or other) normative justificatory logics, this can just as easily happen in reverse (by evaluating moral, strategic, or legal principles in terms of their political legitimacy). The point of talking of empowered collective agency as an 'intrinsic' political value, and of legitimacy principles as embodying a distinctively political normativity, is thus not to insulate them from moral or other forms of normative critique, but rather to emphasize the structural autonomy of their internal justificatory logics. 
Adopting a collective agency account of political legitimacy - rather than a moral or epistemic account - matters not only for philosophical debates about the justification of democracy, but also for political debates about the design and development of democratic institutions. These varying normative accounts of legitimacy typically converge in affirmation of the legitimizing role of various electoral and deliberative democratic social choice institutions. But collective agency accounts can additionally recognise the legitimizing role played by some more diffusely institutionalized collective agencies, which do not meet the same moral and epistemic standards as formal social choice procedures, but nonetheless play important roles in forming and expressing common interests within groups. Familiar examples of such practices, invoked by 'collective agency' democrats as sources of legitimacy, include the 'public cultures' of nations, harnessed by democratic ideals of legitimate national selfdetermination, ${ }^{21}$ and the 'civil society' organizations and networks central to associational democratic ideals. ${ }^{22}$

However, there is no principled reason to think that national cultures and civil societies are the only kinds of collective practices that can embody such valuable collective agency. Although these have contributed substantially to the legitimacy of democratic states over the last two centuries, it is not so clear that legitimacy in a global era can be adequately supported by democratically empowering only national and civil society collectives. While nations and civil society associations are still actively engaged in many global governance contexts, collective political agency can now be found in a more diverse and complex array of global institutional configurations, which traverse the traditional institutional boundaries of political collectives. Examples include: international policy and advocacy networks, which traverse boundaries among states; ${ }^{23}$ 'multi-stakeholder' governance processes, which traverse boundaries between states and civil societies; ${ }^{24}$ and transnational 'economic supply chain' governance practices, which traverse boundaries between civil societies and economic actors. ${ }^{25}$ Such global practices embody collective political agency insofar as they play important roles in defining and expressing the common interests that drive global governance - and their empowerment may thus play

21 (Miller 1995)

22 Paul Hirst, Associative democracy: New forms of economic and social governance (John Wiley \& Sons, 2013); Mark Warren, Democracy and Association (Princeton University Press, 2001).

23 Anne-Marie Slaughter, 'Global government networks, global information agencies, and disaggregated democracy', Mich. J. Int'l L., 24 (2002), p. 1041; Eva Sørensen and Jacob Torfing (eds.), Theories of democratic network governance (London: Palgrave, 2007); Rod Rhodes, 'The new governance: governing without government', Political studies, 44/4, (1996), 652-667.

24 K Bäckstrand, 'Multi-stakeholder partnerships for sustainable development: rethinking legitimacy, accountability and effectiveness', Environmental Policy and Governance, 16/5, (2006), 290-306.

25 Kate Macdonald, The politics of global supply chains (Cambridge: Polity Press, 2014). 
an important role in generating legitimate democratic governance in the global political era, as nations and civil societies have done in earlier historical periods.

It must of course be acknowledged that not all of the collective practices driving global governance embody valuable forms of agency, of the kind that warrant respect as sources of political legitimacy. Sometimes collectives in global governance contexts express and pursue interests that are dominating, harmful, or imprudent to the degree that the empowerment of such collectives corrodes rather than strengthens the legitimacy of governance institutions. Any more fine-grained collective agency account of political legitimacy must therefore specify criteria for identifying which forms of collective agency warrant respect and political support, and when and how empowering existing collective practices can strengthen legitimacy.

Elsewhere, I argue that an account of this kind can be developed by pursuing the insight that not all respect-worthy value judgments made by political agents are expressed communicatively, in response to cognitive faculties of deliberation and decision-making - for instance through an electoral vote or deliberative voice. ${ }^{26}$ Rather, they may also be expressed behaviorally within other kinds of social practices, ${ }^{27}$ in response to non-cognitive evaluative faculties such as attention and emotion, which steer individuals' wider patterns of adaptation and resistance to governance institutions. ${ }^{28}$ While such faculties do not tend to produce optimal moral or epistemic judgment, they warrant the respect of democrats insofar as they undergird the creative dimensions of political agency, ${ }^{29}$ which are crucial in helping political collectives adapt to change, solve new problems, manage complex social conflicts, and regenerate and reenergize mutual commitments across time and generations. ${ }^{30}$

It is beyond the scope of this article to develop or apply this account in the kind of detail required to demarcate which specific range of global collective practices would qualify as respect-worthy, and sources of legitimacy, on these terms. But for the present purposes, it is sufficient to work from the provisional premise that some significant range of transnational collective practices -

26 List and Koenig-Archibugi (2010); Iris Marion Young, Inclusion and democracy (Oxford: Oxford University Press, 2002).

27 Raymond Geuss, 'What is political judgement?', in Richard Bourke and Raymond Geuss (eds.) Political Judgement: Essays for John Dunn (Cambridge: Cambridge University Press, 2009); Mark Philp, Political Conduct (Cambridge, MA: Harvard University Press, 2007); Jonathan Floyd, 'Normative behaviourism and global political principles', Journal of International Political Theory 12/2 (2016), 152-168.

28 Macdonald (2018).

29 Hans Joas, The Creativity of Action, (Chicago: University of Chicago Press, 1996).

30 Some dimensions of creative agency are arguably invoked, albeit in different language, within theories that link legitimacy to the special forms of agency involved in complex political problem-solving - whether understood in realist (Williams (2005)), rationalist (Buchanan (2014); Buchanan and Keohane (2006)), or pragmatic (De Búrca, Keohane, \& Sabel (2014)) terms. 
reaching beyond the familiar cases of nations and civil society associations will qualify. Here, my aim is just to unpack the implications of this premise, should it be accepted, for the question of how democratic boundaries should be delineated.

If we approach the task of delineating democratic boundaries with a view to strengthening the political legitimacy of governance institutions, then the starting assumptions we adopt about the normative sources of political legitimacy turn out to matter a great deal. Collective agency accounts of democratic legitimacy, in general, imply what Christian List and Mathias Koenig-Archibugi have called a 'performative' formulation of the democratic boundary problem - which is focused on identifying the functions that a demos needs to be able to perform, and the characteristics that it needs to possess to be able to perform these functions effectively. ${ }^{31}$ On this view, getting democratic boundaries right requires institutionalizing the way that groups of individuals interact, through democratic governance institutions, so they can function together effectively as a democratically self-determining collective agency.

To translate this abstract idea of democratic collective agency into a concrete account of legitimate democratic boundaries, we must specify the kinds of institutional processes through which collective democratic agency is constituted. On democratic accounts that tie legitimacy narrowly to the forms of agency exercised through social choice procedures, the conditions for democratic collective agency are defined in the narrow sense of capacity for collective decision. ${ }^{32}$ On these accounts, the kind of valuable collective agency that is a source of legitimacy is located narrowly in the demos, defined as participants in democratic decision-making procedures. Other political agencies within the democratic institutional scheme - in particular, the agents of public power that create and wield the governance capabilities required to carry out collective decisions - are then regarded as legitimate only when they are strongly subordinated to the agency of the demos. Such agencies of public power can include for example the bureaucratic and operational infrastructures of states or formal International Organizations, as well as the looser social and economic infrastructures of transnational markets and networks, which facilitate the mobilization of resources and expertise in discharging governance functions. ${ }^{33}$

31 List and Koenig-Archibugi (2010).

32 See for instance List and Koenig-Archibugi (2010), pp. 94-96.

33 The distinction between social choice and public power cannot be equated straightforwardly with the distinction between 'legislative' and 'executive' powers within a constitutionalized democratic institutional scheme, despite the obvious functional parallels. It is a more sociologically fundamental distinction than this, in that it pertains to the deep sociological structures that constitute the most basic sources of political agency within a social order (those that can then create and legitimize both legislative and executive public powers). 
But broader interpretations of the collective agency account such as that sketched here - which recognize a wider range of collective practices as respectworthy forms of collective agency and sources of legitimacy - can recognize many processes for constituting public power as independent contributors to the legitimacy of governance processes. This is so insofar as it is plausible to regard them as respect-worthy expressions of practice-based (as distinct from choice-based) dimensions of collective political agency. What is distinctive about some of the contemporary transnational governance practices noted earlier - such as those involving international policy networks, multi-stakeholder processes, and supply chain governance - is that their processes for expressing and strategically pursuing interests are not formally divided between 'decisionmaking' and 'executive' agencies. Rather, participants express their interests to a large degree through active efforts to get things done, and bring about desired social, economic, or wider political outcomes directly. Within institutionally hybrid practices of this kind - traversing traditional democratic distinctions between states, civil societies, economies, and functional arms of government - many of the expressive functions theoretically assigned to social choice procedures are performed instead, in practice, through the collective exercise of more direct forms of public power. ${ }^{34}$

What then are the implications of this recognition for the delineation of democratic boundaries? So far, I have only established some quite general distinctions between the collective agencies of the demos and public power, and between the contributions each can in principle make to the political legitimacy of democratic governance institutions. But the implications of these distinctions for democratic boundary questions depend further on establishing the dynamics of interaction between the distinct collective agencies of a demos and public power within institutional practice, in the overall exercise of collective political self-determination within a democratic institutional scheme. It is to these institutional questions, accordingly, that I turn my attention next.

\section{The institutional interdependence of the demos and public power: linking democratic minds to their bodies politic}

Through what analytic frame can we most clearly capture the complex institutional dynamics through which the decision-making collective agencies of

34 An inescapable corollary of this argument is that the distinction between 'public' and 'private' power will be a matter of ongoing political contestation, based on differing judgments of whether particular institutions advance some genuinely collective interest; as such, this distinction is not something that can (in all or even most cases) be drawn philosophically and codified in law, as in the ideal-typical democratic 'state.' While contestation over attributions of 'public' status to institutional power inevitably complicate broader normative contestations over legitimacy, there is no principled reason for thinking this must be any less intractable than parallel contestation over the 'representative' status of decision-makers vis a vis the demos - which is already a routine feature of political contestation over the democratic legitimacy of governance within states. 
global demoi, and the practice-based collective agencies of global public power, interact to generate legitimate democratic self-determination? A key challenge here is identifying a frame that can structure analysis of the complex empirical dynamics of political control within governance institutions, while maintaining a clear focus on the dimensions of control that constitute collective agency in the normative sense that is the source of political legitimacy. I propose that a heuristic frame of precisely this kind can be found in the classical theoretical metaphor of the political collective as differentiated, institutionally, between its ruling mind and its material body politic.

More specifically, a simple but vivid way of conceptualizing the functionally interdependent institutional relationship between the agencies of a demos and public power, within an overarching democratic collective, is to think of them as analogous to the relationship between elements of mind and body, within the overarching agency of an individual person. On a fairly standard model of individual agency, a person is considered to have acted when the movements of her body are substantially responsive to (albeit not fully determined by) a decision taken in her mind, expressed in what we sometimes call a will. On this model, the body functions both to give causal power to a person's will in the external world and thus translate it into effective agency, and to delimit the scope of that agency, as a function of the limited range of outcomes that her body is physically capable of producing; a person's agency is both enabled by the physical powers of her body and constrained by its weaknesses and vulnerabilities. Philosophical models of individual agency vary widely in the roles they attribute to its non-cognitive dimensions - such as faculties of emotional and attentional responsiveness - and they vary too in how they link such faculties analytically to the constructs of mind and body respectively. But notwithstanding these ambiguities, thinking of agency as structured through some kind of functional mind/body division nonetheless supplies a familiar and serviceable heuristic frame for the normative analysis of agency, which can be instructively transposed to analysis of the collective political case.

The agency of a democratic unit is constituted institutionally rather than biologically, but the basic structure of its agency is analogously bifurcated between the interdependent functions of will-formation and material interaction with the external world. The former corresponds with the social choice institutions that constitute the demos, and function as the metaphorical mind of the democratic polity. The latter correspond with the governance capabilities that we call public power; these function as the metaphorical body of the democratic polity - or to redeploy the corporeal metaphor of classical political theory, the body politic. 
The use of this corporeal agency metaphor in the theory of political legitimacy is perhaps most familiar from the famous image on the original cover of Hobbes' Leviathan, with the head of the sovereign on a body constituted by the multitude of individual subjects. In this image, the collective agency of the state-based polity is presented as constituted through a dynamic relationship between two distinct sources of political agency: the animating agency of the body politic, driven by collisions among a diversity of individual interests; and the rationalizing agency of the ruling sovereign mind. But in the subsequent shift from a Hobbesian to a democratic theoretical understanding of collective political agency as a source of political legitimacy, something important in this image has been lost. In the democratic image, the leviathan is turned on its head: the unilateral ruling mind of the sovereign is supplanted by the rule of the many, constituted through the collective mind of democratic social choice. But with this migration of the multitude from the body to the mind of the collective agent, the prominence of the body politic as a source of agency with some independence from ruling mind is substantially diminished.

My key claim here is that this shift is problematic for democratic theory and creates a misleading picture of the character of collective agency within a legitimate institutional scheme. In the Hobbesian image the ruling mind does not erase the agency of the body politic, but merely rationalizes it; what I am proposing is that this older insight should be restored within the democratic theory of political legitimacy. Instead of seeing the process of democratization as a shift of the agency of the many from the body politic to the decision-making mind, we should rather see collective political agency as distributed across both. Political legitimacy, on this view, is produced through an institutional structure that connects these institutions of political mind and body together in a way that ensures the exercise of public power is appropriately responsive to the decisions reached by a demos - via direct participation, representation, or other democratic institutional means - while not conflating the agency of public power with that of the demos.

It is important to emphasize that this idea of institutional responsiveness does not require a uni-directional relationship between democratic mind and body. In other words, it does not imply that the demos should be constituted to make decisions independently from its interactions with institutions of public power, or that institutions of public power can legitimately exercise power only as an inert instrument of the decisions made through a demos's social choice procedures. On the contrary, the normative model of collective agency sketched above - which highlights the importance of recognizing practice-based dimensions of political agency that extend beyond procedurally-structured 
choice-making - leaves substantial space for some more independent forms of agency to be exercised through public power institutions, within the overarching framework of democratic collective self-determination. The challenge, then, is to identify how collective agency, within a legitimate democratic unit, should be exercised beyond the framework of a demos's social choice procedures. We must consider: what are the institutional processes through which the practice-based agency of public power should be exercised, and how should these interact with the decision-making agency of the demos, in order to constitute an overarching institutional framework of legitimate democratic governance?

Providing a complete theoretical answer to these questions would require developing a much more extensive normative account of practice-based collective agency, which is beyond the scope of this paper. Here my more modest aim is just to identify a minimum or baseline contribution that must be made by the practice-based agency exercised through public power, as a function of feasibility constraints on the scope of the political agency that can be exercised through social choice procedures. ${ }^{35}$ More specifically, I want to offer some reasons for thinking that feasibility constraints impose particularly strong limits on the collective agency that can be exercised through social choice procedures in the context of complex and large-scale global governance, and that practicebased forms of collective agency in general must therefore play a particularly significant role in delineating the scope of public power in this global context.

To see this, we must start by raising and challenging the notion that the agency of public power institutions can be wholly subordinated to the agency of a decision-making demos in the sense that it can be within the power of the demos to decide what kinds of institutions of public power to create, and what functional scope they ought to possess. Here, the historically influential theoretical metaphor of the social contract, along with associated mythologies surrounding the founding moments of political societies, may invite the supposition that institutions of public power can be summoned into existence through an act of collective will by the members of some demos, and that their most significant empirical preconditions will therefore be the endorsement of their justifying reasons by these individuals. Even assuming that the members of a demos can feasibly reach agreement about general normative standards for the justification of a shared framework of public power, however, I contend that there is still another major condition that would need to be satisfied before a demos could succeed in setting up a functional framework of public power, which we can call the competency condition. This is the requirement that the demos

35 In doing so I proceed on the assumption that ought implies can in the specific sense that the normative legitimacy attributed to democratic institutions on the collective agency account must be attributable to forms of collective agency that can feasibly function in real democratic governance practice. 
as a collective decision-making agent must not only have adequate knowledge, insight, and understanding to identify correctly the kinds of institutions that will be effective in bringing about the outcomes willed by the group, but also know how to bring these institutions about.

To achieve competencies of these kinds, the members of a demos - acting collectively - would first need to be able to perform a number of cognitive feats: to articulate comprehensively what would be entailed in the kind of social outcome that is being sought by the democratic will, and diagnose corresponding deficits in the status quo; to identify accurately the underlying causes of the present social realities that are the target of transformative political action; to devise on this basis functionally effective material technologies and infrastructures (such as military or information systems, depending on the content of the goals being pursued) and/or organizational systems (such as bureaucracies, firms, or other specialized functional agencies) that could succeed in bringing about the desired transformations; and then to calculate strategically how individual roles and material resources would need to be allocated and coordinated within the organizational system so as to bring about the required outcomes. Performing these feats would require not only the capacity to acquire and analyze vast quantities of information, but also to undertake enormous creative and imaginative leaps of strategic innovation, at the levels of both technological and organizational design.

Overcoming these challenges is not impossible in principle, or under all circumstances; there are some sufficiently simple issue-areas or smallscale problems for which a well-informed and well-functioning demos could successfully design appropriate material and organizational infrastructures to tackle them effectively. In relation to many large and complex social problems, however - such as those confronted at the level of global governance these challenges are enormous. It is my contention that the limits upon the competence of a single group agent to undertake successful projects of largescale social engineering are such that we cannot expect efforts by a demos to design and construct an entire apparatus of public power from scratch, in order to empower itself in the activity of collective self-rule, could succeed. This point seems especially incontrovertible if the kind of demos we are most interested in empowering is constituted across multiple issue-areas, and on a global scale, under the current highly complex social conditions of globalization.

Indeed, for all that I said above about the tendency of the social contract metaphor to deflect attention away from this problem about the origins of public power, it is in fact a problem of which the seminal social contract thinker 
Rousseau was deeply aware. Rousseau questioned whether a workable design for fundamental social institutions can be landed upon 'by a sudden inspiration' within a group, asking:

How will a blind multitude, which often does not know what it wills because it rarely knows what is good for it, carry out an undertaking as great, as difficult as a system of legislation? By itself the people always wills the good, but by itself it does not always see it. The general will is always upright, but the judgment which guides it is not always enlightened. ${ }^{36}$

The solution Rousseau proposes is reliance on the elusive figure of the 'Lawgiver,' which requires 'superior intelligence' and something akin to divine powers to perform the required role: as he puts it, '[i]t would take gods to give men laws.' 37 This idea of the Lawgiver remains one of the most puzzling features of Rousseau's argument in the Social Contract - though this is perhaps little wonder, given the intractability of the problem that the idea is thrown up to solve. Certainly - if the appearance of a divine figure such as Rousseau's Lawgiver is a necessary pre-requisite for a demos to establish a successful framework of public power for itself, this should not instill great optimism about its prospects of success.

Is there, then, another kind of solution to the problem at hand - one that does not rely on the competence of a demos to design and construct an institutional framework of public power for itself from scratch, as an instrument for achieving collectively willed goals? I suggest that there is. To see it we must begin with the recognition that it is entirely possible in principle that a task of institutionbuilding that is beyond the competence of a group of individuals constituted as a demos - that is as a single collective agent undertaking reasoning and decision-making through social choice institutions - need not also be beyond the cumulative capacity of that same group of individuals operating through their multiple and overlapping social and institutional roles within the social order as a whole. The development of a framework of public power within a democratic institutional unit can thus occur not through an act of collective decision, but rather through a developmental process, in political practice, that can be characterized as a kind of co-optation of private social structures and institutions by emergent or established demoi - where the label private denotes institutions that have not (yet) been structured by public normative principles of legitimate democratic governance.

36 Jean-Jacques Rousseau, 'Of the Social Contract', in Victor Gourevitch (ed.) The Social Contract and Other Later Political Writings (Cambridge: Cambridge University Press, 1997), p. 68.

37 Ibid., p. 69. 
Such a possibility can potentially be realized, I suggest, through a dynamic interaction between two parallel processes of institutional development. The first involves the spontaneous development of social institutions with a range of powers and capacities at relatively low levels of scale and complexity, established to serve the various shared goals of their respective participants. These can sometimes take the form of organizationally formalized group agents - such as sovereign states, corporations, International Organizations, or transnational NGOs. But they can also include more diffuse institutional frameworks for collective agency that have not (at least yet) developed the collective decisionmaking structures constitutive of demoi - such as the collective practices of international policy networks, multi-stakeholder processes, and supply chain governance, discussed above.

The second parallel process involves the systematic political co-optation of these private institutions through attempts, by some emergent demos, to steer and gain control of them, and in so doing to harness their powers in the service of the wider group. Here groups affected directly by the external consequences of private institutional activities may be motivated to mobilize collectively to gain some effective form of control over these institutions. In doing so, they can both: curtail the most harmful and readily preventable negative externalities of the existing social institutions or abuses of their power; and harness the institutional powers and capacities of these institutions to the service of any wider collective goals that the group may identify. In this way, the material and organizational infrastructures of private institutions can be co-opted by emergent demoi - or in other words, private power can be converted into public power.

To translate this all back into the corporeal collective agency imagery discussed earlier, the democratization of global politics cannot be achieved through an exclusive focus on democratizing the global decision-making procedures that constitute the ruling mind; rather, we must consider how to democratize the global bodies politic that emerge, through political practice, as the sites and sources of governance capability within a global institutional scheme. This very general model of institutional development - in which the creation of institutions of public power has some sociological independence from the development of social choice institutions aimed at legitimating that power - resonates with Thomas Nagel's observation in the related debate about the proper scope of duties of justice, that "political power is rarely created as a result of demands for legitimacy, and that there is little reason to think that things will be different in this [global] case.' 38 


\section{Democratizing global bodies politic: Towards a pluralist model of democratic boundaries}

So far, I have sketched somevery general feasibility constraints on the competence of a demos to control the scope of its institutions of public power through social choice procedures, which show why the boundaries of democratic units must to some degree accommodate the structure of governance capabilities emerging through political practice. In this final section, I will explore the implications of these general arguments for more concrete questions about the design of democratic institutions and the delineation of their boundaries in the context of global politics.

One straightforward way to connect my somewhat abstract arguments about collective political agency to more concrete institutional models is to reflect, first, on how they are able to capture the real forms of collective political agency driving the development and democratic legitimization of public power in the familiar historical case of state institutions. This kind of historical reflection can illuminate the normative analysis of legitimacy insofar as our theories aim to interpret critically and make intellectual sense of our realpractices of democratic legitimization, rather than to construct philosophical ideals of democratic legitimacy detached from the realities of political life. ${ }^{39}$ In doing so, I suggest that the plausibility of the developmental model of institutional 'co-optation' outlined above - as a paradigmatic model of democratic collective agency - is enhanced by its strong resonance with established historical accounts of the real forms of political agency driving state emergence and democratization. It is beyond the scope of this paper to offer the kind of detailed historical analysis that could vindicate this claim in any robust way, but a brief look at the case is at least suggestive.

In doing so, we can note strong similarities between my general theoretical model, and the account of political institutional development developed by John Dewey in relation to sovereign states. In The Public and its Problems, ${ }^{40}$ Dewey describes a process whereby the institutional infrastructures of states were developed initially to serve the private interests of monarchs (and their associates), and then only later taken over by wider publics whose members were affected by the externalities of these institutions. In illustrating this account, he highlights the instance of the 'King's Peace' in twelfth century England as '[a]n interesting phase of the transition from the relatively private to the public, at least from a limited public to a larger one. ${ }^{41}$ He traces the

\footnotetext{
39 Taylor (2004).

40 John Dewey, The Public and Its Problems, (Denver: Allen Swallow, 1927).

41 Ibid., pp. 47-48.
} 
process through which the administration of justice by feudal and shire courts was forced to pass incrementally to the King's courts, as a means of increasing monarchs' revenues and expanding their power and prestige. But then once established, this institutional apparatus could straightforwardly be converted into a framework for serving the function of justice administration on behalf of the wider 'public' that was significantly affected by the operation of these institutions. ${ }^{42}$ As he describes it: '[a] measure instigated by desire to increase the power and profit of the royal dynasty became an impersonal public function by bare extension. ${ }^{43}$

Dewey focuses more in his analysis on the conversion from private to the public function of institutions, and less on the conversion from private to public control, via the agency of an established demos. This makes sense since at the stage of institutional development Dewey describes the demos and the institutional framework of public power (in my terms) were developing in tandem - the demos through the galvanizing effect of common subjection to the external effects of powerful private institutions, and the framework of public power through the incremental conversion of the functions of these powerful institutions from private to public, driven by the political force of the claims made by affected populations.

It would be an interesting exercise also to extend this historical analysis through later stages of democratization in the case of this state. Some historical analysis focusing on this later stage can be found in Robert Goodin's (2010) discussion of global democratization processes, in which he picks up on this example of English state-building and democratization at a later date and traces the process forwards through the development of mechanisms for controlling the arbitrary exercise of power within these new public institutions of the state, prior to the development of electoral institutions and richer forms of public democratic control. A rigorous historical analysis of the relationship and mutual interplay between the development of institutions for advancing public functions (of the kind emphasized by Dewey) and the development of institutions for public democratic decision-making and control (of the kind emphasized by Goodin) would provide an instructive means of exploring the dynamics and assessing the validity of the abstract developmental model that I have presented - as would case-studies focused on other democratic states during the development of their original frameworks of sovereign public power. Although I cannot offer such historical analysis here, I hope that what I have said is enough at least to

42 More specifically, he says that a 'public' is a group that 'consists of all those who are affected by the indirect consequences of transactions to such an extent that is deemed necessary to have those consequences systematically cared for' (Ibid., pp. 15-16).

43 Ibid., p. 48. 
render plausible the idea that my broad institutional model of the development of democratic collective agency offers a useful interpretation of the forms of political agency driving the development of legitimate democratic institutions in the case of (at least some) states.

If so, this may lend some support to the proposal that a similar developmental pathway might be open for the expansion of democratic legitimization within the sphere of global politics, under conditions of globalization. This recognition points us towards a particular strategy for approaching the question of where to draw the boundaries of democratic units in global politics: beginning not with analysis of the criteria for delineating a demos, but rather with analysis of the forms of institutionalized political power that exist within the wider social order as viable platforms for the development of a democratic political apparatus.

This strategy requires us to begin the delineation of democratic boundaries with an empirically-informed analysis of the institutionalized governance practices in which global public power is constituted and emerging. In such empirical analysis, it is now commonplace to observe that the social and political transformations associated with globalization have significantly eroded the dominance of sovereign state-based governance institutions. Instead, much public power is now exercised beyond the boundaries of nation-states, through the transnational operations of institutions such as International Organizations, Multinational Corporations, and International Non-Governmental Organizations (INGOs). Moreover, democratically functioning demoi have not yet been created at corresponding levels with the capacity to reach unified democratic decisions about the proper control of such power. It follows from this that political efforts at democratization, too, should be targeted at these multiple institutional levels.

My proposed account of collective agency and democratic institutional development thus lends strong support to what is sometimes called a model of global public power and democracy. ${ }^{44}$ In a pluralist model of democratic governance, the mobilization of demoi through social choice procedures is organized around myriad state, inter-governmental, and non-state agents of public power operating at multiple and overlapping 'jurisdictional' levels, not unified by any one supreme global political authority or hierarchy of constitutional principles. The pluralist model thus proposes that the democratic boundary question should be settled not through the design and pursuit of idealized blueprints for nationalist or cosmopolitan democracy, based on the view that the most properly constituted demoi are to be found at one of those

44 Krisch (2011); Macdonald and Macdonald (2010); Macdonald (2015); Terry Macdonald, Global Stakeholder Democracy: Power and Representation Beyond Liberal States (Oxford: Oxford University Press, 2008); Philip Cerny, 'Plurality, Pluralism and Power: Elements of Pluralist Analysis in an Age of Globalization', in Rainer Eisfeld (ed.) Pluralism: Developments in the Theory and Practice of Democracy (Opladen and Farmington Hills: Barbara Budrich Publishers, 2006), 81-111. 
two levels - but rather by locating existing structures of political power (with productive potential) within the global social order, and then working towards their incremental democratic co-optation and control.

The pluralist model of global democratization presents some enormous challenges for building democratic theories and institutions, since so many of our democratic conceptions and institutional models have been developed with state-based structures of public power in mind. For a start, the pluralist model raises the prospect that a given individual will be a member not of a single demos but rather of multiple overlapping demoi. Each of these will be configured in relation to one of the various powerful institutions that impact significantly upon her life, while also providing the institutional means for the advancement of some set of her important (social) goals. This prospect challenges the familiar ideal of democratic citizenship as membership and equal status within a single bounded political unit, and accordingly as associated with some fundamental source of social identity. In contrast, the pluralist model depicts membership in a given demos as just one institutional role among many that an individual will undertake, and therefore one that is likely to be more detached from her deeper sources of social identity and status.

Moreover, the realization of a pluralist model of democracy would require development of new institutional mechanisms for democratic social choice and political control that are capable of functioning effectively within the crosscutting and fluid political boundaries of a pluralist order. In relation to social choice mechanisms, electoral mechanisms may be unappealing and unworkable within at least some of these multiple demoi, for two reasons. The first of these is that establishing stable operational electoral processes within many fluid and overlapping constituencies would raise logistical complexities that may be too difficult to overcome. The second is that a simple assumption underlying the normative justification of elections that give each individual an equal vote - the assumption that each individual will have a roughly equal stake in the outcome - is unsustainable in relation to at least some of the institutions of public power within a pluralist order; this assumption is unsustainable because the impacts of institutional decisions on populations affected by or participant in the institutions can be very uneven, and give some much higher stakes than others. As an additional consequence of this need for a diminished reliance on elections, it would be necessary to devise more flexible and open processes of authorization and accountability (based on forms of stakeholder input other than votes cast in elections) to foster effective political control of the plural agencies of public power. ${ }^{45}$

45 For more in-depth discussions of these issues, and the possibility of non-electoral mechanisms of social choice and political control - authorization and accountability - see Macdonald (2008). 
There would also be further serious challenges associated with a global democratic system organised around a pluralist structure of public power, insofar as the lack of centralization or coordination of roles and responsibilities within the system overall would permit both gaps and duplications in the powers and responsibilities held by different actors in the system. This may hinder effective democratic accountability by creating uncertainty and ambiguity regarding which powerful actors should be held accountable for which political outcomes. Finally, the geographically dispersed and culturally diverse profiles of many of the overlapping demoi within such a system would create challenges for the task of establishing effective and legitimate processes of social choice and political control, to the extent that communication and coordinated collective political action is likely be more difficult than within territorially concentrated and culturally homogenous groups.

\section{Conclusions}

Elsewhere I have discussed these challenges in some detail and offered some proposals about how we might begin thinking about how to overcome them. ${ }^{46} \mathrm{It}$ is not the place here to pursue these further, however, since my goal in this paper has not been to elaborate in detail or offer a full normative defense of a pluralist model of global democracy. Rather, my goal has been to offer a theoretical rationale - at a much higher level of generality - for taking a pluralist approach to the task of global democratic institution-building.

I cannot conclude on the basis of what I have said here that this approach will ultimately be successful. Pointing out this open pathway towards global democratization does not imply the teleological inevitability of its ultimate achievement; nor does my argument imply that this is the only strategic pathway open to its pursuit. Rather, I have argued that this pathway is one that both respects the valuable forms of collective political agency embodied in a range of new transnational governance practices, and harnesses the transformative potential of their creative political power. In pointing to these reasons, my aim has been to give strong grounds for thinking that this pluralist approach is at the least a promising one, and worthy of further intellectual work. But the prospects for converting this transformative potential into robustly legitimate global institutions must - as in all democratic systems - depend ultimately on the dynamic judgments and commitments of political collectives themselves.

As John Dewey observed in relation to the case of the sovereign state, an institutional framework of public power,

is not created as a direct result of organic contacts as offspring are conceived in the womb, nor by direct conscious intent as a machine is

46 Macdonald (2008); Macdonald (2018). 
invented, nor by some brooding indwelling spirit, whether a personal deity or a metaphysical absolute will. ${ }^{47}$

No more should we expect the institutional foundations for a system of democratic global governance to emerge in some such manner. Instead of waiting for the conditions to be perfect for the implementation of some ideal institutional blueprint devised through grand philosophical design, we must work with what we've got, institutionally speaking, and regard the project of global democratization as a long-term work-in-progress. Right now, what we've got 'to go to work on,' as $\mathrm{Nagel}^{48}$ has put it, is a complex and fragmented institutional framework of power - and it is from these albeit unsteady foundations that we can hope for a more democratic global political order (slowly) to be built.

Terry Macdonald

Senior Lecturer

School of Social and Political Sciences

University of Melbourne

Email:terry.macdonald@unimelb.edu.au

\section{the global justice network}

